\title{
The Effect of Delphi-based Learning Media on the Students' Learning Outcomes in Electricity and Electronic Lessons Reviewed from the Level of Independence Learning Students
}

\author{
Bagus Dwi Cahyono ${ }^{1}$, Supari Muslim ${ }^{2}$, Joko $^{3}$, Bima Anggana Widhiarta $\mathbf{P}^{4}$ \\ State University of Surabaya \\ baguscahyono16070895013@mhs.unesa.ac.id
}

\begin{abstract}
The purpose of this study is to: (1) analyze the differences in learning outcomes between students who study using Delphi-based learning media and students who learn by using Power Pont learning media in Basic Electrical and Electronics subjects at Surabaya KAL-1 Vocational School; (2) analyze the differences in learning outcomes in Basic Electrical and Electronics subjects between students who have a high level of learning independence and students who have a low level of learning independence at Surabaya KAL-1 Vocational School; (3) analyzing the interaction between the use of instructional media (delph and PPT) and the level of learning independence on learning outcomes in the Basic Electrical and Electronics subjects at the Surabaya KAL-1 Vocational School. This type of research is quasi-experimental using factorial $2 \times 2$ design, and the data were analyzed using Anacova two lines with the help of SPSS. The study found: (1) Learning outcomes for students using Delphibased learning media (cognitive domain mean $=79$ ) were significantly higher than learning outcomes for students who used Point Power learning media (cognitive domain = 73) in Basic Electricity subjects and Electronics at KAL 1 SMK Surabaya; (2) Learning outcomes for students who have TKBT (cognitive domain average $=78.17$ ) are significantly higher than learning outcomes for students who have TKBR (cognitive domain average $=74.35$ ) in Basic Electrical and Electronics subjects at KAL Vocational School. 1 Surabaya; (3) there is a significant interaction between the use of learning media (Delphi and PPT) and the level of learning independence on cognitive learning outcomes in the Basic Electrical and Electronics subjects at the Surabaya KAL-1 Vocational School. Research suggests: (1) Selection of learning media should be done appropriately especially if the school already has adequate infrastructure; (2) teachers in learning must be able to pay attention to the characteristics of students (learning independence) so that students are able to master the material better; and (3) learning media as a source of learning must be able to be maximally utilized by students in its use.
\end{abstract}

Keywords: Delphi based learning media, learning outcomes, student learning independence, and vocational school.

\section{INTRODUCTION}

Education is a shared responsibility, both community and government. One of the efforts made by the government to improve education in Indonesia is to make the 2013 Education Curriculum an improvement of the 2006 Curriculum or the Education Unit Level Curriculum (KTSP). In the development of the 2013 Curriculum requires students to study more independently, discipline in managing time, and carry out more directed and intensive learning activities so that the objectives of the implementation of the 2013 Curriculum can be achieved well [1].

In learning activities, independence is very important because independence is a personal attitude that is needed by every individual. According to Utari Sumarmo with independence, students tend to learn better, be able to monitor, evaluate, and manage their learning effectively, save time efficiently, will be able to direct and control themselves in thinking and acting, and not feeling dependent on others emotionally. Students who have learning independence are able to analyze complex problems, are able to work individually or work with groups, and dare to express ideas. Learning where students just sit quietly and listen to information from the teacher seems to have become entrenched since a long time ago, so that to make changes towards active, creative, and pleasant learning is indeed difficult [2]. 
In Audio Video Engineering (TAV) Expertise Competence in Surabaya KAL 1 Vocational School there are competencies that must be mastered by students, one of them is Basic Electricity and Electronics competencies. Mastery of Basic Electricity and Electronics material is needed, because the material is a basic material that will be very useful for further learning materials such as Digital Electronics learning material and Microcontroller learning material.

Based on the results of observations at KAL 1 Surabaya Vocational School, learning in Basic Electrical and Electronics subjects in class X of the TAV Skills Competency in the even semester of the 2017/2018 academic year obtained less than optimal learning outcomes. The learning outcomes obtained when observing were that most students obtained grades below the KKM with minimum completeness criteria (KKM) 75 (Provisions for the KKM Expertise Program for the TAV Vocational School 1 Surabaya), so it needed to be given a remedial to obtain complete learning outcomes. This is because during learning some students do not pay attention to the teacher's explanation, students also do not read textbooks and do not work on worksheets if not asked or ordered by the teacher and when the teacher gives homework students do not do it at home. Such conditions indicate a lack of independence of students in learning Basic Electricity and Eletronics subjects. Based on the background above, this study aims to: (1) analyze learning outcomes for students taught with

using learning media based on delphi and students taught by using PPT learning media on Basic Electrical and Electronics subjects at Surabaya KAL-1 Vocational School; (2) analyze the differences in learning outcomes in Basic Electrical and Electronics subjects between students who have a high level of learning independence and students who have a low level of learning independence at Surabaya KAL-1 Vocational School; (3) analyzing the interaction between the use of instructional media (delph and PPT) and the level of learning independence on learning outcomes in the Basic Electrical and Electronics subjects at the Surabaya KAL-1 Vocational School.

\subsection{Delphi Based Learning Media}

\section{LITERATUR REVIEW}

Learning media is needed in learning activities to convey the contents of a subject matter delivered by the teacher which is useful for motivating student learning [3]. media in learning are all forms of communication tools that can be used to convey information from sources (teachers) to students who aim to attract them to participate in learning activities. Media is not only used to convey learning material and can be used to provide reinforcement and motivation in teaching and learning activities [4]. Learning media used in this study are based on Delphi. Delphi is a software made by Borland that is very popular. Unlike Windows software in general, Delphi is not application software, such as MS Office or games [5]. Thus it can be concluded that media learning based on Delphi is an application based on Delphi ready to install containing material and exercises about the subject matter of Electricity and Eletronics which can help students understand the material and complete the task independently. The form of Delphi based learning media is shown in figure 1 below.

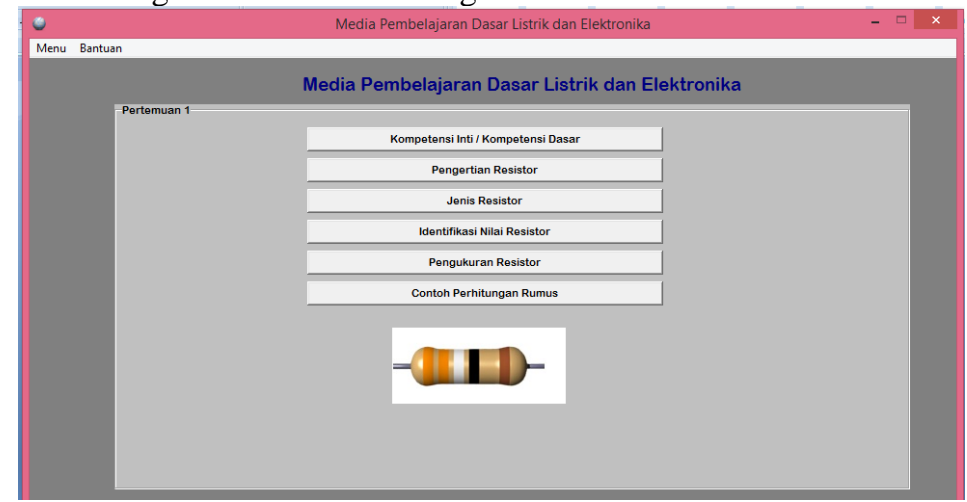

Figure 1. Delphi-Based Learning Media (Source: Data researcher, 2018)

\subsection{Level of Student Learning Independence}

According to Mandailina [6], the use of learning media based on Delphi can increase the level of learning independence of students who have the characteristics of being able to take initiative, be able to 
overcome obstacles / problems, have self-confidence and can do things themselves without the help of others. Independence of learning is also interpreted as the ability to stand alone in the sense of not relying on others in determining decisions and being able to carry out life's tasks with full responsibility [7]. Thus it can be stated that the use of Delphi-based learning learning can increase the level of student learning independence, so that they are able to complete tasks and tests independently and responsibly with satisfactory results.

\subsection{Student learning outcomes}

The use of delphi based learning media can affect student learning outcomes. Learning outcomes will appear in every change in these aspects such as: knowledge, understanding, habits, skills, appreciation, emotional, social relations, physical, ethical or ethical character and attitude [8]. Learning outcomes are changes in student behavior due to learning. Behavior change is caused because he achieves mastery over a number of materials given in the teaching and learning process. Achievement is based on predetermined teaching goals. The results can be changes in cognitive, or psychomotor aspects [9]. In the learning process it needs to focus on the learning objectives of the three domains, namely: (1) the cognitive domain is a change in thinking ability; (2) affective domain which is a change in behavioral abilities; and (3) psychomotor domain which is a change in skills [10]. From the opinion of several experts above, it can be concluded that learning outcomes are the acquisition of student learning processes and the occurrence of changes in student behavior due to learning activities that involve three domains, namely: cognitive domain, affective domain and psychomotor domain. In this study only the cognitive domain learning outcomes data were used only.

\subsection{Basic Electricity and Electronics Basic Competencies}

Basic competency is a number of abilities that must be mastered by students in certain subjects as a reference for the preparation of competency indicators in a lesson [11]. Referring to the Electrical Engineering syllabus of Class X of KAL 1 Surabaya Vocational School for Basic Electrical and Electronics Subjects, the basic competencies used in this study are as follows.
a. Basic Knowledge Competencies
: 3.8 Understanding RLC passive components
b. Basic Competency Skills
: 4.8 Measuring passive components of RLC

\subsubsection{Basic Material for Electricity and Electronic}

\section{a. Electricity and Electronic Component}

The electrical component is composed of several electronic components, while the electronic component is part of an electrical component. Examples of electronic components are: diodes, cathodes, transformers, resistors, and ICs. While examples of electrical components are: meter ampere, switch, fuse, and voltmeter [12].

Examples of passive electronic components are as follows.

1. Capacitors

Capacitors are tools / devices to temporarily store electric charges. A simple capacitor / condenser composed of two parallel metal plates is insulated from each other by an insulating material called a dielectric [13]. The type of capacitor is named according to the dielectric, for example: paper, mica, ceramics, and so on.

2. Resistor

Resistors are passive electronic components that function to inhibit and regulate electric current in an electronic circuit. The unit of resistor value or resistance is ohm $(\Omega)$. Resistor values are usually represented by numeric codes or colored bracelets found in the resistor body [13].

3. Inductor

Inductors (coils) commonly called "Coils" are components that are composed of wire windings. Inductors include components that can store electric charges. The basic form of an inductor is a wire that is wrapped into a coil [13]. Coils have air core, iron core, or ferrite core. The value of an inductor is called an inductance with a basic unit of Henry.

In the classroom learning process about basic competencies understanding the passive components of RLC, it requires learning media that contain learning material and practice questions to facilitate students in understanding learning material and applying some basic electronic formulas in problem 
training. Besides students must master the passive RLC component material, but students must also be able to identify and measure the value of passive RLC components. The learning media used in this study are delphi based learning media. Delphi is a programming language that can be used in making an interactive and interesting application. In addition, the superiority of delphi based learning is an application that is easy to operate in various PC specifications without the need to install the Delphi program, so this will make it easier for students to understand the material learning better RLC passive components [14].

The advantages of Delphi compared to other programming languages include [15]:

1. Based on Object Oriented Programming (OOP). Each part of the program is seen as an object that has properties that can be changed and regulated.

2. The final result is one * .exe file. After the program is designed in the Delphi IDE (Integrated Development Environment), Delphi will compile it into a single executable file. Programs that are created can be directly distributed and run on other computers without the need to include DLL files from outside. This is a very significant advantage.

3. Borland Delphi 7 comes with Borland Kylix 3 based on Linux, allowing programmers to create multiplatform applications.

4. This program is accompanied by pictures, animations, and simulations that make the display more attractive, interactive, attractive and practical.

5. Delphi-based application program that can be used to solve electronic calculation questions along with steps to get the solution.

6. The results of installing Delphi can be used without having to install the Delphi software first.

\section{RESEARCH METHODS}

The method used in this study is a quasi-experimental method with a $2 \mathrm{X}$ factorial design design. Factorial design uses two groups, namely: (1) the experimental group is students of class X TAV 1 who learn using learning media based on Delphi; and (2) the control group is students of class X TAV 2 who study with using PPT learning media, with a moderator variable on the level of student learning independence.

Table 1: Treatment by level 2 X 2 design

\begin{tabular}{cccc}
\hline \multirow{2}{*}{ No } & Level of independence & \multicolumn{2}{c}{ Media $(\mathbf{Y})$} \\
\cline { 3 - 4 } & & Delphi Based $\left(\mathbf{Y}_{1}\right)$ & $\begin{array}{c}\text { Power Point } \\
\left(\mathbf{Y}_{2}\right)\end{array}$ \\
\hline 1 & High level of independence $\left(\mathrm{K}_{\mathrm{t}}\right)$ & $\mathrm{K}_{\mathrm{t}} \mathrm{Y}_{1}$ & $\mathrm{~K}_{\mathrm{t}} \mathrm{Y}_{2}$ \\
\hline 2 & Low level of independence $\left(\mathrm{K}_{\mathrm{r}}\right)$ & $\mathrm{K}_{\mathrm{r}} \mathrm{Y}_{1}$ & $\mathrm{~K}_{\mathrm{r}} \mathrm{Y}_{2}$ \\
\hline
\end{tabular}

Information:

Kt Y1 = Student learning outcomes using Delphi-based learning media for students with TKBT.

Kt Y2= Student learning outcomes using PPT learning media for students with TKBT.

$\mathrm{Kr}$ Y1 = Student learning outcomes using Delphi-based learning media for students with TKBR.

$\mathrm{Kr}$ Y2 = Student learning outcomes using PPT learning media for students with TKBR.

Data collection techniques used in this study, are through: (1) observation; (2) tests of cognitive learning outcomes; and (3) student learning independence questionnaire. The instruments used in this study were: (1) learning media validation sheets, (2) learning device validation sheets, and (3) student learning independence questionnaire validation sheets. The instrument test conducted at SMK PGRI 4 Surabaya was to find out: (1) the validity of the item; (2) the level of difficulty of the item; (3) different power indices; and (4) different power analysis. The data analysis technique used is Anacova two lines with the help of SPSS, by applying the prerequisite test, namely the nomination test, homogeneity test, and the independent sample $t$ test.

\section{RESUlts}


The collected data is obtained through student learning outcomes tests and the observation sheet is then used as data in this study. The results of data collection from the class learned by using Delphi-based learning media and classes that were taught using PPT learning media are still in the form of raw scores. For the purposes of statistical tests on research data, then the raw score is changed to the raw score. Data description is carried out to explain: (1) student TKB data; and (2) learning outcomes of cognitive domain students. Learning class learning outcomes data using the Delphi based learning and learning classes that use PPT learning media were obtained from: pre-test scores to determine students' initial abilities and post-test scores for cognitive learning outcomes.

\subsection{Student Data}

\subsubsection{Learning Outcomes The Cognitive Realm of Learning Classes Using Delphi-Based Learning} Media

The learning outcomes of the cognitive domain of the Basic Electricity and Electronics class subjects that were taught by Delphi-based learning media were used pre-test questions and post-test questions in Table 2 below.

Table 2. The pretest and posttest values of the experimental and control classes

\begin{tabular}{|c|c|c|c|c|c|}
\hline \multicolumn{3}{|c|}{ Experimental } & \multicolumn{3}{|c|}{ Control } \\
\hline $\begin{array}{c}\text { No. } \\
\text { Absent }\end{array}$ & Pretest & Posttest & $\begin{array}{c}\text { No. } \\
\text { Absent }\end{array}$ & Pretest & Posttest \\
\hline 1 & 45 & 85 & 1 & 45 & 75 \\
\hline 2 & 40 & 82 & 2 & 40 & 80 \\
\hline 3 & 50 & 85 & 3 & 60 & 75 \\
\hline 4 & 35 & 80 & 4 & 30 & 70 \\
\hline 5 & 50 & 85 & 5 & 50 & 75 \\
\hline 6 & 35 & 80 & 6 & 35 & 70 \\
\hline 7 & 30 & 85 & 7 & 30 & 80 \\
\hline 8 & 30 & 90 & 8 & 30 & 80 \\
\hline 9 & 30 & 88 & 9 & 30 & 70 \\
\hline 10 & 35 & 88 & 10 & 35 & 60 \\
\hline 11 & 40 & 85 & 11 & 40 & 60 \\
\hline 12 & 45 & 84 & 12 & 45 & 80 \\
\hline 13 & 25 & 80 & 13 & 30 & 70 \\
\hline 14 & 50 & 88 & 14 & 50 & 80 \\
\hline 15 & 30 & 75 & 15 & 35 & 75 \\
\hline 16 & 30 & 90 & 16 & 30 & 78 \\
\hline 17 & 30 & 80 & 17 & 30 & 75 \\
\hline 18 & 45 & 70 & 18 & 45 & 75 \\
\hline 19 & 30 & 78 & 19 & 30 & 70 \\
\hline 20 & 30 & 75 & 20 & 40 & 85 \\
\hline 21 & 35 & 80 & 21 & 35 & 65 \\
\hline 22 & 35 & 72 & 22 & 40 & 70 \\
\hline 23 & 40 & 75 & 23 & 40 & 75 \\
\hline 24 & 40 & 74 & 24 & 40 & 70 \\
\hline 25 & 40 & 70 & 25 & 35 & 72 \\
\hline 26 & 45 & 75 & 26 & 35 & 75 \\
\hline
\end{tabular}




\begin{tabular}{|l|l|l|l|l|l|}
27 & 40 & 72 & 27 & 40 & 78 \\
\hline 28 & 40 & 75 & 28 & 40 & 65 \\
\hline 29 & 25 & 80 & 29 & 45 & 75 \\
\hline 30 & 35 & 80 & 30 & 35 & 80 \\
\hline 31 & 40 & 78 & 31 & 35 & 65 \\
\hline 32 & 40 & 70 & 32 & 35 & 70 \\
\hline 33 & 35 & 75 & 33 & 40 & 80 \\
\hline 34 & 35 & 75 & 34 & 40 & 70 \\
\hline & & & 35 & 35 & 75 \\
\cline { 5 - 6 } & & & 36 & 35 & 60 \\
\cline { 5 - 6 } & & & & &
\end{tabular}

From the score of cognitive learning outcomes of students in the learning class using Delphi-based learning media in appendix 2 which if processed with SPSS will produce descriptive statistics on SPSS. From the results of SPSS, it was found that the data for the pretest scores of students in the experimental class were as follows: the mean was 37.05; standard deviation is 6.86; the lowest value is 25 ; and the highest value is 50 . Meanwhile for the posttest value data of students in the experimental class are as follows: the mean value is 79.52; standard deviation is 5.97; the lowest value is 70; and the highest value is 90 .

4.1.2 Learning Outcomes The Cognitive Realm of Learning Classes Using PPT-Based Learning Media

The learning outcomes of the cognitive domains of Basic Electricity and Electronics class subjects that were taught with PPT-based learning media were used in the pre-test and post-test questions in Table 2 above. From the score of cognitive learning outcomes of students in the learning class using PPT-based learning media in appendix 3 which if processed with SPSS will produce the output of SPSS statistics. From the results of the SPSS above, it was found that the data for the pretest scores of students in the control class were as follows: the mean value was 37.91; standard deviation is 6.80; the lowest value is 30 ; and the highest score is 60. Meanwhile for the data on the posttest value of students in the control class are as follows: the mean value is 73 ; standard deviation is 6.22 ; the lowest value is 60 ; and the highest value is 85 .

\subsubsection{Level of Student Learning Independence}

The level of student learning independence was measured using a questionnaire with five answer choices, namely: SS (Strongly Agree), S (Agree), KS (Less Agree), TS (Disagree), and STS (Strongly Disagree). This questionnaire is used to find out students who have high TKB and students who have low TKB given before the learning process begins. Questionnaire about the level of student learning independence there are 20 statements using five alternative answers. From the questionnaire level of student learning independence questionnaire above, the lowest total score is 0 and the highest score is 100 . The total score of the level of independence is between 0-50 and the total score of the level of high independence is between 51-100. Data on the level of student learning independence in the control and experimental classes in Table 3 below.

Table 3. Scores of the students' independence in the experimental and control classes

\begin{tabular}{|c|c|c|}
\hline No. Absent & $\begin{array}{c}\text { Students' } \\
\text { Independence } \\
\text { Control Class }\end{array}$ & $\begin{array}{c}\text { Students' Independence } \\
\text { Experimental Class }\end{array}$ \\
\hline 1 & 80 & 80 \\
\hline 2 & 70 & 45 \\
\hline 3 & 50 & 70 \\
\hline 4 & 45 & 88 \\
\hline
\end{tabular}




\begin{tabular}{|c|c|c|}
\hline 5 & 78 & 40 \\
\hline 6 & 75 & 50 \\
\hline 7 & 45 & 70 \\
\hline 8 & 60 & 30 \\
\hline 9 & 68 & 35 \\
\hline 10 & 25 & 80 \\
\hline 11 & 35 & 60 \\
\hline 12 & 25 & 30 \\
\hline 13 & 70 & 40 \\
\hline 14 & 80 & 78 \\
\hline 15 & 45 & 88 \\
\hline 16 & 78 & 35 \\
\hline 17 & 80 & 88 \\
\hline 18 & 30 & 78 \\
\hline 19 & 78 & 35 \\
\hline 20 & 80 & 40 \\
\hline 21 & 25 & 70 \\
\hline 22 & 45 & 35 \\
\hline 23 & 48 & 60 \\
\hline 24 & 35 & 70 \\
\hline 25 & 45 & 45 \\
\hline 26 & 70 & 48 \\
\hline 27 & 38 & 38 \\
\hline 28 & 70 & 70 \\
\hline 29 & 78 & 78 \\
\hline 30 & 75 & 75 \\
\hline 31 & 80 & 80 \\
\hline 32 & 88 & 88 \\
\hline 33 & 76 & 76 \\
\hline 34 & 76 & 76 \\
\hline 35 & 45 & \\
\hline 36 & 50 & \\
\hline
\end{tabular}

From table 3 above, it is obtained data that in the data control class students who have TKBT are 17 students and 17 students of TKBR, while in the experimental class data students who have TKBT are 18 students and TKBR 18 students.

\subsection{Assumption Test}

\subsubsection{Normality Test}

a. Normality Test Score Learning Outcomes Cognitive Realm of Experimental Class

The normality test results are used to test whether the scores obtained are normally distributed or not. The normality test used is the Kolmogorov-Smirnov test. The results of normality testing can be seen as shown in Table 4 . 
Table 4. Normality Test Results Score Learning Outcomes Cognitive Realm of Experimental Class

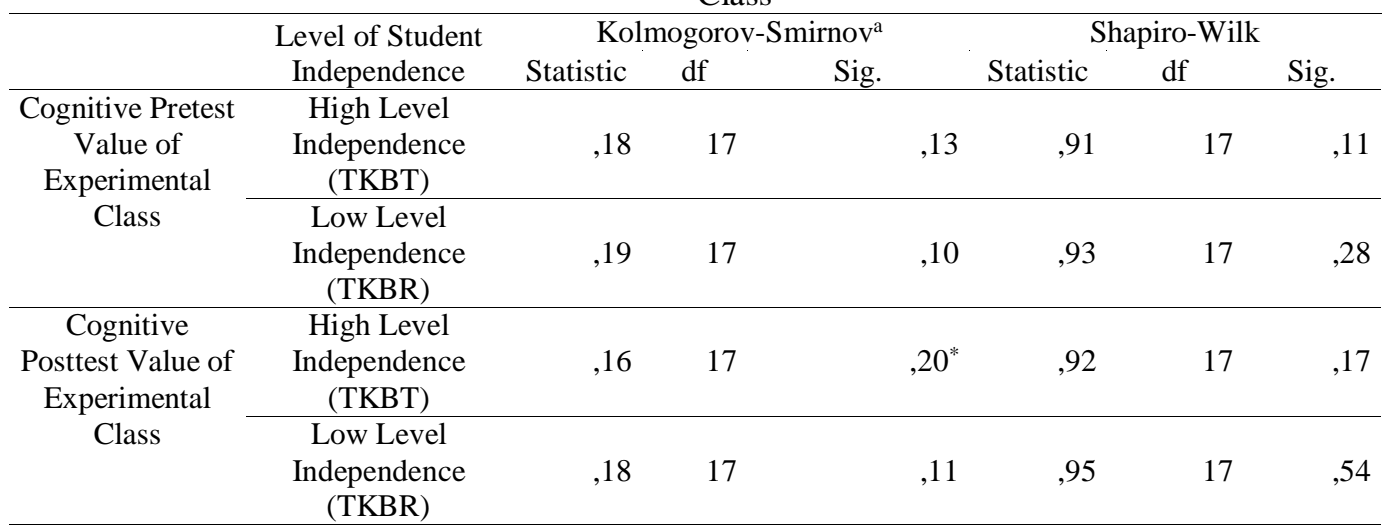

Learning outcomes data are said to be normally distributed if the significance values obtained from the normality test are> 0.05 . From Table 4 it appears that the results of the normality test scores on the cognitive domains of the pretest experimental class for the TKBT and TKBR groups are the significance values of 0.13 and 0.10 . While the results of the normality test scores on the learning outcomes of the experimental class cognitive posttest for the TKBT and TKBR groups were the significance values of 0,20 and 0.11 . The statistical data show that the scores of the experimental class cognitive learning outcomes for the TKBT and TKBR groups using the Kolmogorov-Smirnov test have significance> 0.05 , thus the cognitive learning outcomes scores for the experimental class pretest and posttest for the TKBT and TKBR groups were normally distributed.

\section{b. Normality Test Score Learning Outcomes Cognitive Realm of Experimental Class}

The normality test results are used to test whether the scores obtained are normally distributed or not. The normality test used is the Kolmogorov-Smirnov test. The results of normality testing can be seen as shown in Table 5.

Table 5. Normality Test Results Score Learning Outcomes Cognitive Realm of Experimental Class

\begin{tabular}{|c|c|c|c|c|c|c|c|}
\hline & \multirow{2}{*}{$\begin{array}{l}\text { Level of Student } \\
\text { Independence }\end{array}$} & \multicolumn{3}{|c|}{ Kolmogorov-Smirnov $^{\mathrm{a}}$} & \multicolumn{3}{|c|}{ Shapiro-Wilk } \\
\hline & & Statistic & $\mathrm{df}$ & Sig. & Statistic & $\mathrm{df}$ & Sig. \\
\hline \multirow{2}{*}{$\begin{array}{c}\text { Cognitive Pretest } \\
\text { Value of } \\
\text { Experimental } \\
\text { Class }\end{array}$} & $\begin{array}{c}\text { High Level } \\
\text { Independence (TKBT) }\end{array}$ & ,25 & 18 & ,06 & ,87 & 18 & ,06 \\
\hline & $\begin{array}{c}\text { Low Level } \\
\text { Independence (TKBR) }\end{array}$ & ,24 & 18 & ,06 & ,86 & 18 & ,06 \\
\hline \multirow{2}{*}{$\begin{array}{c}\text { Cognitive } \\
\text { Posttest Value of } \\
\text { Experimental } \\
\text { Class }\end{array}$} & $\begin{array}{c}\text { High Level } \\
\text { Independence (TKBT) }\end{array}$ &, 17 & 18 &, 18 & ,95 & 18 & ,42 \\
\hline & $\begin{array}{c}\text { Low Level } \\
\text { Independence (TKBR) }\end{array}$ & ,13 & 18 & ,20* & ,94 & 18 & ,32 \\
\hline
\end{tabular}

Learning outcomes data are said to be normally distributed if the significance values obtained from the normality test are> 0.05. From Table 4.8 it appears that the results of the normality test scores on the cognitive domains of the pretest control class for the TKBT and TKBR groups are a significance value of 0.06 and 0.05 . While the results of the normality test scores on the learning outcomes of the cognitive posttest control class for the TKBT and TKBR groups were the significance values of 0.18 and 0.20 . It can be concluded, that the scores on the cognitive domain of the control class for the TKBT and TKBR groups using the Kolmogorov-Smirnov test have a significance of $>0.05$, thus the cognitive learning outcomes scores for the pretest and posttest control classes for the normal distribution of TKBT and TKBR groups.

\subsubsection{Homogeneity Test Score Learning Outcomes Cognitive Domain Experimental and Control} Classes

The homogeneity test of cognitive domain learning scores between the class groups taught by Delphi learning media and the class taught with PPT learning media was used to determine whether or not the variance between the two groups was the same. In this study to test the variance used Levene's. To test the homogeneity, the SPSS 20 program was used, as shown in Table 6. 
Table 6. Test of Homogeneity Score of Learning Outcomes Cognitive Realm of Experiment and Control Classes

\begin{tabular}{|c|c|c|c|c|c|c|c|}
\hline \multicolumn{4}{|c|}{ Cognitive Pretest Value of Experimental Class } & \multicolumn{4}{|c|}{ Pretest Value of Cognitive Control Classes } \\
\hline Levene Statistic & df1 & df2 & Sig. & $\begin{array}{l}\text { Levene } \\
\text { Statistic }\end{array}$ & df1 & df2 & Sig. \\
\hline 1,24 & 1 & 32 & ,27 & 31 & & 34 &, 58 \\
\hline \multicolumn{4}{|c|}{ Cognitive Posttest Value of Experimental Class } & \multicolumn{4}{|c|}{ Cognitive Posttest Value of Control Class } \\
\hline Levene Statistic & df1 & df 2 & Sig. & $\begin{array}{c}\text { Levene } \\
\text { Statistic }\end{array}$ & df1 & df2 & Sig. \\
\hline 1,21 & 1 & 32 & 0,27 & 0,41 & & 34 & 0,49 \\
\hline
\end{tabular}

Based on the test results of the homogeneity of the test scores in the table above, the significance value of the experimental class was obtained for the pretest and posttest values of 0.27 and 0.27. Meanwhile for the control class the pretest and posttest values were 0.58 and 0.49 . The statistical data shows that the sample variance is homogeneous.

\subsubsection{Independent Sample T Test}

After obtaining data on the initial ability of the control class students and the normal and homogeneous experimental class, then the analysis of the independent sample t test was carried out. From the results of the analysis test using the independent sample $t$ test using SPSS 21 software to produce the output in Table 7.

Table 7. Independent sample t test values pretest test experimental class and control class

\begin{tabular}{|c|c|c|c|c|c|c|}
\hline & \multicolumn{6}{|c|}{ Test Value $=37$} \\
\hline & \multirow[b]{2}{*}{$\mathrm{t}$} & \multirow[b]{2}{*}{ df } & \multirow[b]{2}{*}{ Sig. (2-tailed) } & \multirow{2}{*}{$\begin{array}{c}\text { Mean } \\
\text { Difference }\end{array}$} & \multicolumn{2}{|c|}{$\begin{array}{l}\text { 95\% Confidence Interval of the } \\
\text { Difference }\end{array}$} \\
\hline & & & & & Lower & Upper \\
\hline $\begin{array}{c}\text { Cognitive Pretest } \\
\text { Value of } \\
\text { Experimental Class }\end{array}$ & 05 & 33 & 96 & ,058 & $-2,33$ & 2,46 \\
\hline $\begin{array}{c}\text { Cognitive Pretest } \\
\text { Value of Control } \\
\text { Class }\end{array}$ & ,80 & 35 & ,42 & ,91 & $-1,38$ & 3,21 \\
\hline
\end{tabular}

Based on the one sample $t$ test data in Table 7 above, the significance value of the experimental class and the control class is 0.96 and 0.42 . Because the number of significance is $>0.05, \mathrm{H} 0$ is accepted, which means there is no significant difference between the initial ability of the control class and the experimental class. So that it can be given treatment.

\subsubsection{Hypothesis Test}

Testing the hypothesis value is the last step used to decide whether the temporary answer from the problem statement mentioned in the research hypothesis is true or false. In other words, statistical hypothesis testing also means if the null hypothesis is accepted or rejected. The statistical hypothesis test used is Anacova 2 lines. The test results are as shown in Table 8.

Table 8. Test of Hypothesis Statistics on Learning Outcomes in the Cognitive Realm

\begin{tabular}{crrrrr}
\hline Source & Type III Sum of Squares & df & Mean Square & \multicolumn{1}{c}{ F } & \multicolumn{1}{c}{ Sig. } \\
\hline Corrected Model & $1483,01^{\text {a }}$ & 3 & 494,33 & 18,15 &, 00 \\
\hline Intercept & 406809,01 & 1 & 406809,01 & 14941,83 &, 00 \\
\hline media & 745,47 & 1 & 745,47 & 27,38 &, 00 \\
\hline independence & 253,88 & 1 & 253,88 & 9,32 &, 00 \\
\hline $\begin{array}{c}\text { media } * \\
\text { independence }\end{array}$ & 503,48 & 1 & 503,48 & 18,49 &, 00 \\
\hline Error & 1796,92 & 66 & 27,22 & & \\
\hline Total & 409426,00 & 70 & & & \\
\hline Corrected Total & 3279,94 & 69 & & &
\end{tabular}


1. Learning outcomes for students who use Delphi-based learning media are significantly higher than learning outcomes for students who use Power Point learning media on Basic Electrical and Electronics subjects at KAL 1 Vocational School Surabaya

In Table 8 it appears that the results of testing the hypothesis obtained a significance value of 0.00 . If the test is carried out at $\alpha=5 \%$, df1 $=(3-1)=2$, df $2=(70-3)=67$, so the value of Ftable is 3.11. Because Fcount $=27.38>$ Ftable $=3.11$, then $\mathrm{H} 1$ which reads the learning outcomes for students using Delphi learning media is significantly higher than the learning outcomes for students who use PPT learning media in learning Electricity and Electronics at SMK KAL- 1 Surabaya is accepted and $\mathrm{H}_{0}$ which reads the learning results for students using Delphi learning media is the same as learning outcomes for students who use PPT learning media in Basic Electricity and Electronics learning in Surabaya KAL-1 Vocational School are rejected, meaning cognitive learning outcomes for students who are taught using Delphi learning media is significantly higher than cognitive domain learning outcomes for students who are taught using PPT learning media in Basic Electricity and Electronics learning at Surabaya KAL-1 Vocational School. Next to support the research hypothesis, the mean test is further used, as shown in Table 9 below.

Table 9. Mean Value of Learning Outcomes in the Cognitive Domain in Experiment and Control Classes

\begin{tabular}{crrrr}
\hline & & & \multicolumn{2}{c}{$95 \%$ Confidence Interval } \\
\cline { 4 - 5 } Learning Media & Mean & Std. Error & Lower Bound & \multicolumn{1}{c}{ Upper Bound } \\
\hline Delphi & 79,52 &, 89 & 77,74 & 81,31 \\
\hline PPT & 73,00 &, 87 & 71,26 & 74,73 \\
\hline
\end{tabular}

In Table 9 it appears that the mean score of cognitive learning outcomes for students using Delphi learning media is 79.52 significantly higher than the cognitive learning outcomes using PPT learning media which is 73 .

2. Learning outcomes for students who have TKBT are significantly higher than learning outcomes for students who have TKBR on Basic Electricity and Electronics subjects at KAL 1 Vocational School Surabaya

In Table 8 it appears that the results of hypothesis testing obtained Fcount of 9.32 with a significance value of 0.00 . If the test is carried out at $\alpha=5 \%$, df1 $=(3-1)=2$, df $2=(70-3)=67$, so the value of Ftable is 3.11. Because Fcount $=9.32>$ Ftable $=3.11$, then H1 which reads the learning outcomes for students who have a significantly higher TKBT than learning outcomes for students who have TKBR in Basic Electricity and Electronics learning at Surabaya KAL-1 Vocational School is accepted and $\mathrm{H} 0$ which reads the learning results for students who have the same TKBT as the learning outcomes for students who have TKBR in Basic Electricity and Electronics learning at Surabaya KAL-1 Vocational School is rejected, meaning cognitive domain learning outcomes for students who have higher TKBT compared to students who have TKBR. Next to support the research hypothesis, the mean test is used, as shown in Table 10.

Table 10. Mean Values of Learning Outcomes in the Cognitive Domain in TKBT and TKBR Groups

\begin{tabular}{ccrrr}
\hline & & & \multicolumn{2}{c}{$95 \%$ Confidence Interval } \\
\cline { 4 - 5 } Student Level Independence & Mean & Std. Error & Lower Bound & Upper Bound \\
\hline High Level Independence & 78,17 &, 88 & 76,40 & 79,93 \\
\hline Low Level Independence & 74,35 &, 88 & 72,59 & 76,12 \\
\hline
\end{tabular}

Table 10 above shows that the mean cognitive learning outcomes of students who have TKBT and TKBR. Where the mean score of cognitive learning outcomes of students who have TKBT is 78.17, while students who have TKBR are 74.35.

3. There is a significant interaction between the use of instructional media and the level of student learning independence towards student learning outcomes in the Basic Electrical and Electronics subjects at KAL 1 Vocational School Surabaya 
In Table 8 it appears that the results of testing the hypothesis obtained Fcount of 18.49 with a significance value of 0.00 . If the test is carried out at $\alpha=5 \%$, df1 $=(3-1)=2$, df $2=(70-3)=67$, so the value of Ftable is 3.11. Because Fcount $=18.49>$ Ftable $=3.11$, then $\mathrm{H}_{1}$ which says there is an interaction between the use of Delphi learning media, the PPT and TKB learning media of students towards the learning outcomes of Basic Electricity and Electronics at Surabaya KAL-1 Vocational School is accepted and $\mathrm{H}_{0}$ that reads no there is an interaction between the use of Delphi learning media, the PPT and TKB learning media of students towards the learning outcomes of Basic Electricity and Electronics at Surabaya KAL-1 Vocational School rejected, meaning there is an interaction between the use of Delphi learning media, PPT learning media with TKBT and TKBR on cognitive learning outcomes at KAL-1 SMK Surabaya. To explain the interaction, a Table 11 interaction of mean cognitive learning outcomes is made as follows.

Table 11. Interaction of Mean Learning Outcomes of the Cognitive Domain on the Effects of Learning Media and Student TKB

\begin{tabular}{cccrrr}
\hline \multirow{2}{*}{$\begin{array}{c}\text { Learning } \\
\text { Media }\end{array}$} & Student Level & & & \multicolumn{2}{c}{$95 \%$ Confidence Interval } \\
\cline { 5 - 6 } & Independence & Mean & Std. Error & Lower Bound & Upper Bound \\
\hline \multirow{2}{*}{ Delphi } & High Level Independence & 84,118 & 1,266 & 81,591 & 86,644 \\
\cline { 2 - 6 } & Low Level Independence & 74,941 & 1,266 & 72,414 & 77,468 \\
\hline \multirow{2}{*}{ PPT } & High Level Independence & 72,222 & 1,230 & 69,767 & 74,678 \\
\cline { 2 - 6 } & Low Level Independence & 73,778 & 1,230 & 71,322 & 76,233 \\
\hline
\end{tabular}

In Table 11 it appears that the mean price of cognitive learning outcomes for students who have TKBT using Delphi learning media is higher than cognitive domain learning outcomes for students who have TKBT who are taught using PPT learning media. Whereas cognitive domain learning outcomes for students who have TKBR who are taught using Delphi learning media are higher than cognitive domain learning outcomes for students who have TKBT who are taught using PPT learning media. From the two conditions above illustrate there is a relationship of interplay between the Delphi learning media, PPT learning media and student TKB on the cognitive learning outcomes. Where Delphi learning media has a good influence to improve learning outcomes of students who have TBT and PPT learning media have a good influence on improving learning outcomes for students who have TKBR. So in this study there is an interaction between the use of instructional media and student TKB on cognitive learning outcomes. The interaction of the use of instructional media and student TKB on cognitive learning outcomes can be seen in Figure 2.

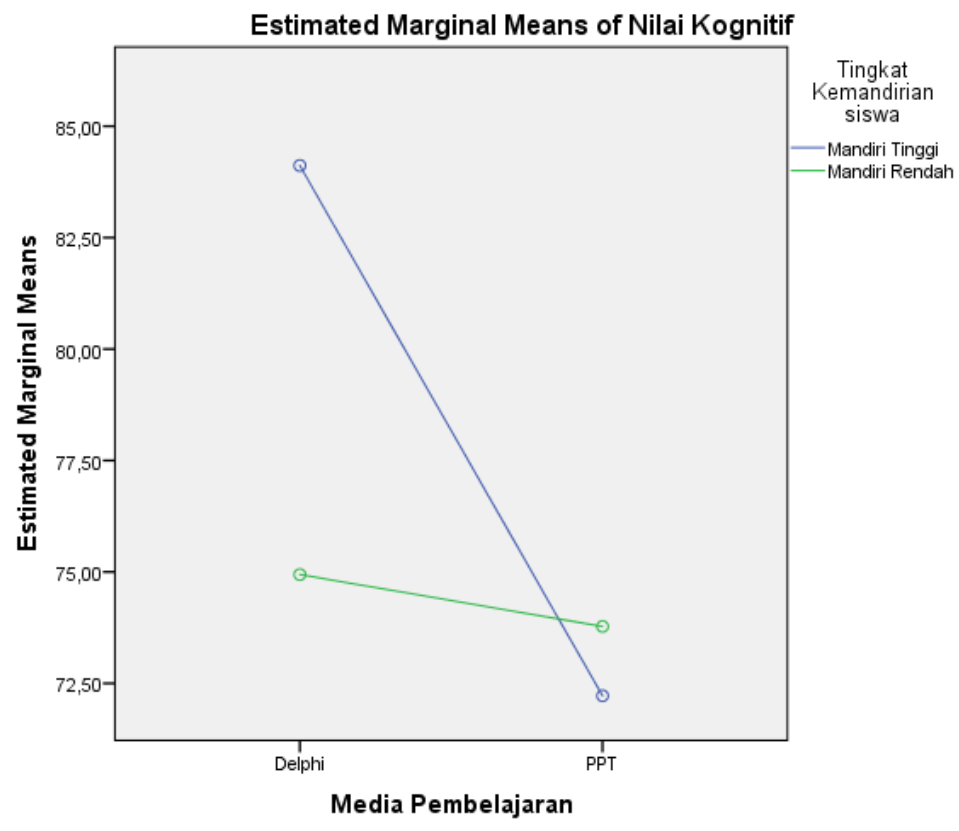

Figure 2. Graph of Line Patterns of Interaction between the Use of Learning Media (Delphi and PPT) and Student TKB Against Learning Outcomes of the Cognitive Domain of Electrical Basic Electricity Electronics 


\section{DISCUSSION}

5.1. Learning outcomes for students who use Delphi-based learning media are significantly higher than learning outcomes for students who use Power Point learning media on Basic Electrical and Electronics subjects at KAL 1 Vocational School Surabaya

Based on the SPSS contribution obtained Fc for cognitive domain learning outcomes on the influence of learning media is 27.38 with 0.00 significance $<0.05$, then $\mathrm{H} 1$ which reads the learning outcomes for students using Delphi learning media is significantly higher than learning outcomes for students who use learning media PPT in Basic Electricity and Electronics learning at Surabaya KAL-1 Vocational School is accepted and H0 which reads learning outcomes for students using Delphi learning media is the same as learning outcomes for students who use PPT learning media in Basic Electric and Electronics learning at KAL-1 Vocational School Surabaya rejected.

From the hypothesis testing of cognitive learning outcomes, it was concluded that the results of students using Delphi learning media were significantly higher than the learning outcomes of students using PPT learning media on Basic Electrical and Electronics subjects at Surabaya KAL-1 Vocational School. So that it can be concluded that Delphi learning media has a good influence on improving student learning outcomes in the cognitive domain.

The results of this study are also in line with previous studies conducted by Mandailina, Syaharuddin, and Pramita [16] entitled "Combination of Delphi Media and Geogebra in Three Dimensional Learning". The study concluded that: (1) the final product developed in the form of an application program that combines Delphi and Geogebra software, and (2) at the expert validation stage there was a valid level of validity, in limited trials the average student gave a good / practical response , and in the field trials the average student responds very well.

The results of this study are also in line with previous studies conducted by Lee, Ang, and Sin Sing [17] entitled "Social media as an informal learning platform: Case study on adult learning at SIM University, Singapore". The study concluded that: by using the Delphi technique a two-round survey of adult students at the end of the school year, the use of digital and social media was obtained as an informal learning platform for adult students.

The results of the study obtained in accordance with the opinion of Sardiman [18] which states that learning media is everything that can be used to channel messages (learning materials), so that students can attract attention, interests, thoughts and feelings in learning activities to achieve certain learning goals. This is in line with Uno [23] which states that media in learning are all forms of communication tools that can be used to convey information from sources (teachers) to students who aim to attract them to participate in learning activities. This is in line with Arsyad [8] learning media is a tool that can be used to convey the contents of a subject matter delivered by the teacher that is useful for motivating student learning. Delphi-based learning media contains Basic Electric and Electronics subject matter which are interactive and interesting so that they can improve student learning outcomes.

\subsection{Learning outcomes for students who have a TKBT are significantly higher than learning outcomes for students who have TKBR on Basic Electrical and Electronics subjects at KAL 1 Vocational School Surabaya}

Based on the calculation of SPSS obtained Fcount for cognitive domain learning outcomes for the influence of student TKB is 9.32 with a significance of $0.00<0.05$, then $\mathrm{H} 1$ which reads the learning outcomes for students who have TKBT significantly higher than learning outcomes for students who have TKBR in Basic Electricity and Electronics learning at KAL-1 Surabaya Vocational High School was accepted and $\mathrm{H} 0$ which reads the learning results for students who have the same TKBT as learning outcomes for students who have TKBR in Basic Electricity and Electronics learning at Surabaya KAL-1 Vocational School was rejected, meaning results cognitive domain learning in students who have a higher TKBT compared to students who have TKBR. From the hypothesis testing of cognitive domain learning outcomes, it was concluded: that the results of students who have a TKBT are significantly higher than the learning outcomes of students who have TKBR on Basic Electrical and Electronics subjects at the Surabaya KAL-1 Vocational School.

The results of this study are in line with previous studies conducted by Surawan, Nurhayata and Sutaya [19] with the title "Application of Self Regulated Learning Models to Improve Student Learning Outcomes of Basic Electromechanical Work Subjects in Class X Students of TIPTL 3 Singaraja 
Vocational High School 3". In this study, it was concluded that: (1) the SRL learning model causes students to be motivated individually or in groups, and can make students more enthusiastic in the learning process so that they can improve student learning outcomes in the cognitive, psychomotor and affective domains; and (2) the application of the SRL learning model can improve the learning outcomes of the Electromechanical Basic Work field of study in class X TIPTL 3 of Singaraja State Vocational High School 3.

The results of this study are in line with previous research conducted by Assagaf [20] entitled "The Effect of Self-Reliance Learning and Self Regulation on Mathematics Learning Outcomes Through Achievement Motivation in Class X Students of State High Schools in Ambon City". The study concluded that: (1) students of class X in the SMA in Ambon City had learning independence, selfregulation, and achievement motivation in the high category, while the learning outcomes were in the medium category; (2) learning independence has a positive effect on mathematics learning outcomes both directly and indirectly through achievement motivation; and (3) self regulation has a positive effect on mathematics learning outcomes both directly and indirectly through achievement motivation.

The independence of learning in this study is caused by: (1) the use of delphi based learning media in learning activities directs students to be independent in doing assignments; (2) students prefer learning using the delphi based learning class (experimental class) compared to PPT learning media (control class); (3) the tasks given by the teacher can be completed by students independently and play an active role in the learning process; and (4) students are able to answer questions with the employee without the help of the teacher.

\subsection{There is a significant interaction between the use of instructional media and the level of student learning independence towards student learning outcomes in the Basic Electrical and Electronics subjects at KAL 1 Vocational School Surabaya}

Based on the SPSS contribution obtained Fc for cognitive learning outcomes on the influence of learning media and student TKB is 18.49 with a significance of $0.00<0.05$, then $\mathrm{H} 1$ which says there is an interaction between the use of Delphi learning media, PPT learning media and student TKB towards Basic learning results of Electricity and Electronics at Surabaya KAL-1 Vocational School were accepted and $\mathrm{H} 0$ which reads that there was no interaction between the use of Delphi learning media, PPT learning media and student TKB on learning results of Basic Electricity and Electronics at Surabaya KAL-1 Vocational School was rejected between the use of Delphi learning media, PPT learning media with TKBT and TKBR on cognitive domain learning outcomes in Surabaya KAL-1 Vocational School. From the testing of hypotheses between cognitive learning outcomes obtained conclusions, that the cognitive learning outcomes there is an interaction between the use of delphi learning media, PPT learning media on learning outcomes Basic Electricity and Electronics at KAL-1 Vocational School Surabaya. Where Delphi learning media is more effective for improving learning outcomes of students who have TKBT and PPT learning media more effective for improving learning outcomes for students who have TKBR. This is due to the attractive and attractive Delphi learning media that make students who have TKBT more active and easy to understand the subject matter. While PPT learning media is less effective for students who have TKBT because PPT learning media are monotonous and less attractive, so students who have TKBT tend to be passive and less able to understand subject matter, and vice versa. The results of this study are in line with previous research conducted by Mulyaningsih [21] entitled "The Effect of Family Social Interaction, Learning Motivation, and Learning Independence on Learning Achievement". The study concluded that: (1) there is a significant influence between social interaction in the family, learning motivation, and learning independence together on student learning achievement; (2) there is a significant influence on family social interaction on student learning achievement; (3) there is a significant effect of learning motivation on student learning achievement, and (4) there is a significant effect of learning independence on student learning achievement.

The results of this study are also in line with previous research conducted by Suryaningsih [22] conducting research on "The Effect of Learning Media and Learning Independence on the Capability of Science Process Skills". This study concludes that: (1) the ability of science process skills students who learn using real media is higher than students who learn using virtual media; (2) there is an influence of interaction between learning media and learning independence on the ability of science process skills; (3) the ability of science process skills students who learn with real media is higher than students who learn with virtual media in groups of students who have high learning independence; and (4) the ability of science process skills of students who study with real media is lower than students who learn with virtual media for students who have low learning independence. 
The interaction between learning media and student TKB on learning outcomes illustrates the relationship between the media and student TKB as factors that influence learning achievement. interaction effects are effects that are caused by the interaction between one independent variable with other independent variables in a media analysis. Thus the interaction effect is the effect caused by the learning media by taking into account the presence of learning independence. The interaction between learning media, student TKB and student learning outcomes provides implications that between learning media and student TKB become a reference in improving student learning outcomes. From the results of the study it can be seen that the use of delphi based learning media is more effective than the use of PPT learning media for groups that have TKBT, while the use of Delphibased learning media is more effective than the use of PPT learning media for groups that have TKBT.

\section{CONCLUSION}

This study concluded that: (1) Learning outcomes for students using Delphi-based learning media (mean cognitive domain $=79.52$ ) were significantly higher than learning outcomes for students who used Point Power learning media (mean cognitive domain = 73) at Basic Electrical and Electronics subjects at SMK KAL 1 Surabaya, so it can be concluded that the Delphi learning media has a good influence on improving student learning outcomes in all three domains; (2) Learning outcomes for students who have TKBT (cognitive domain average $=78.17$ ) are significantly higher than learning outcomes for students who have TKBR (cognitive domain average $=74.35$ ) in Basic Electrical and Electronics subjects at KAL Vocational School. 1 Surabaya, so it can be concluded that the level of student learning independence has a good influence on improving student learning outcomes in all three domains; and (3) There is a significant interaction between the use of instructional media (Delphi and PPT) and the level of student learning independence on student learning outcomes (cognitive domain) in Basic Electrical and Electronics subjects at KAL 1 Surabaya Vocational School, Delphi learning media are more effective in students who have TKBT and PPT learning media are more effective to use for students who have TKBR.

\section{REFERENCES}

[1] Pemerintah Republik Indonesia. (2013). Permendikbud Nomor 32 Tahun 2013 tentang Perubahan atas Permendikbud Nomor 19 Tahun 2005 tentang Standard Nasional Pendidikan. Jakarta: Depdiknas.

[2] Sumarmo, U. (2006). Kemandirian belajar:apa, mengapa, dan bagaimana dikembangkan pada peserta didik. Jakarta: FPMIPA UPI.

[3] Arsyad, A. (2011). Media pembelajaran. Jakarta: Raja Grafindo Persada

[4] Alfian. (2010). Membuat presentasi menakjubkan dengan Microsoft Power Point 2007. Jakarta: Media Kita.

[5] Hendrayudi. ( 2008). Pemrograman Delphi 8.0. Bandung: Yrama Widya.

[6] Husni. (2004). Pemograman database dengan Delphi. Jogyakarta: PT Graha Ilmu.

[7] Mandailina, V., Syaharuddin., \& Pramita, D. (2016). Kombinasi media Delphi dan geogebra dalam pembelajaran dimensi tiga. Paedagoria Vol.14 No.2, 65-72.

[8] Mudjiman, H. (2007). Belajar Mandiri. Surakarta: UNS PRESS.

[9] Pemerintah Republik Indonesia. (2013). Permendikbud Nomor 65 Tahun 2013 tentang Standard Proses. Jakarta: Depdiknas.

[10] Bishop, Owen. 2004. Dasar-dasar Elektronika. Jakarta: PT. Erlangga.

[11] Fadillah, Kismet. 2000. Penerapan Konsep Dasar Listrik Jilid 1. Bandung: PT. Angkasa.

[12] Munadi, Y. (2013). Media pembelajaran. Jakarta: Referensi (GP Press Group).

[13] Ping Jiang, X., Yan, L., Lan Zheng, X., Liu, X., \& Qiong We, X. (2016). Development and evaluation of a new curriculum based on the Delphi method for master of nursing programs in China. Chinese Nursing Research 3 (2), 162-167.

[14] Mandailina, V., Syaharuddin., \& Pramita, D. (2016). Kombinasi media Delphi dan geogebra dalam pembelajaran dimensi tiga. Paedagoria Vol.14 No.2, 65-72.

[15] Lee, B., Ang, \& Sin Sing. (2013). Social media as an informal learning platform:Case study on adult learning at SIM University, Singapore. Social and Behavioral Sciences, $1158-1161$.

Sardiman, A. (2011). Interaksi dan motivasi belajar mengajar. Bandung: PT.Rajawali.

[16] B. Uno, H. (2008). Teori motivasi dan pengukurannya. Jakarta: Bumi Aksara. 
[17] Assagaf, G. (2016). Pengaruh kemandirian belajar dan regulasi diri terhadap hasil belajar matematika melalui motivasi berprestasi pada siswa kelas X SMA Negeri di Kota Ambon. Jurnal Matematika dan Pembelajarannya 2(1), 23-32.

[18] Suryaningsih, E. (2014). Pengaruh media pembelajaran dan kemandirian belajar terhadap kemampuan keterampilan proses sains. Seminar Nasional Evaluasi Pendidikan Tahun 2014 , 149153.

[19] Mulyaningsih, I. (2014). Pengaruh interaksi sosial keluarga, motivasi belajar, dan kemandirian belajar terhadap prestasi belajar. Jurnal Pendidikan dan Kebudayaan, 20(04),441-451.

[20] Musfiqon. (2012). Pengembangan media dan sumber media pembelajaran. Jakarta: PT. Prestasi Pustakarya.

[21] Nasution, S. 2003. Berbagai pendekatan dalam proses belajar \& mengajar. Jakarta: PT. Bumi Aksara.

[22] Nawawi, Adari. (2005). Metode penelitian bidang sosial. Yogyakarta: Gadjah Mada University Press.

[23] Ormrod, J. E. (2004). Human Learning (4th Ed). Ohio: Pearson.

[24] Ozan, C., Gundogdu, K., Bay, E., \& Celkan, H. (2012). A study on the unversity student's self regulated learning strategies skills and self-efficacy perceptions in terms of different variables. Procedia - Social and Behavioral Sciences 46, 1806 - 1811. 